\title{
Molecular genetics of thyroid cancer
}

\author{
MAHA REBAÏ ${ }^{1}$ AND AHMED REBAÏ ${ }^{1} *$ \\ ${ }^{1}$ Laboratory of Molecular and Cellular Screening Processes, Centre of Biotechnology of Sfax, University of Sfax, Route Sidi Mansour, PO Box \\ 1177, 3018 Sfax, Tunisia
}

(Received 9 November 2015; revised 8 March 2016; accepted 5 April 2016)

\section{Summary}

The pathogenesis of the development and progression of thyroid cancer (TC) is far from being clear at present. Accumulated evidence suggests that it is a complex polygenic disorder for which genetic factors play an important role in disease aetiology. Here we review the literature to report the genetic variations and alterations that have been described in the aetiology of TC. The functional effects of some mutations and single nucleotide polymorphisms on TC are validated, establishing the role of sequence variations in this cancer. However, large prospective studies are still required to evaluate the diagnostic and prognostic value of these genetic determinants in clinical practice.

\section{Introduction}

Thyroid cancer (TC) is the most prevalent endocrine malignancy having an incidence two to three times higher in women (Farahati et al., 2004). It can occur at any age although it is more frequent after the age of 30 years and significantly more aggressive in older subjects (Leenhardt et al., 2005). TC is classified into four main histology groups: papillary (PTC), follicular (FTC), medullary (MTC), and undifferentiated or anaplastic thyroid carcinomas. The great majority of malignant thyroid tumours are nonmedullary, either PTC (80-85\%) or FTC (10-15\%) (DeLellis et al., 2006; Kondo et al., 2006).

Molecular analysis of thyroid tumours has indicated that many genetic alterations are found to be involved in cancer development. The most affected genes are those involved in DNA repair, signal transduction and cell cycle control (Kang et al., 2002). In fact, in recent years, a multitude of genetic variations such as mutations and single nucleotide polymorphisms (SNPs) have been identified and associated with TC risk. The most frequent genetic alterations that have been described in papillary and follicular cancers, are $B R A F$ and $R A S$ point mutations and RET/ $P T C$ and $P A X 8 / P P A R \gamma$ rearrangements (Nikiforova

\footnotetext{
* Corresponding author: Tel: +216 74871 816. E-mail: ahmed. rebai@cbs.rnrt.tn
}

\& Nikiforov, 2009). Recently, it has been reported that point mutations in the TERT and TP53 genes are an important event in TC cancer diagnosis or progression (Vinagre et al., 2013; Pita et al., 2014). Yet, recent studies have demonstrated a strong association of some SNPs with TC risk. Among sequence variants that have been highly implicated in the aetiology of TC are the variants at $8 \mathrm{q} 24$ (rs6983267), 9q22.23 (rs965513) and 14q13.3 (rs944289, rs116909374) loci (Gudmundsson et al., 2009; 2012; Sahasrabudhe et al., 2015). These polymorphic sites may affect the enhancer activity of genes or gene regulation, but how they influence these outcomes is not precisely acknowledged.

In a complex polygenic disease such $\mathrm{TC}$, which may be a result of the interaction between a number of genetic and epigenetic factors, analysis of multiple gene polymorphisms and mutations is beginning to be necessary in order to study the susceptibility of the disease. Therefore, in this report, we have reviewed the literature to describe the molecular genetics status of TC.

\section{Thyroid cancer and genetic polymorphisms}

Genome wide association studies (GWAS) have identified some chromosomal regions as new hotspots for TC susceptibility (Table 1 and Fig. 1). These regions are localized at 9q22.33, 14q13.3, $2 \mathrm{q} 35$ and $8 \mathrm{p} 12$. In 
Table 1. SNPs strongly associated with thyroid cancer in genome wide association studies.

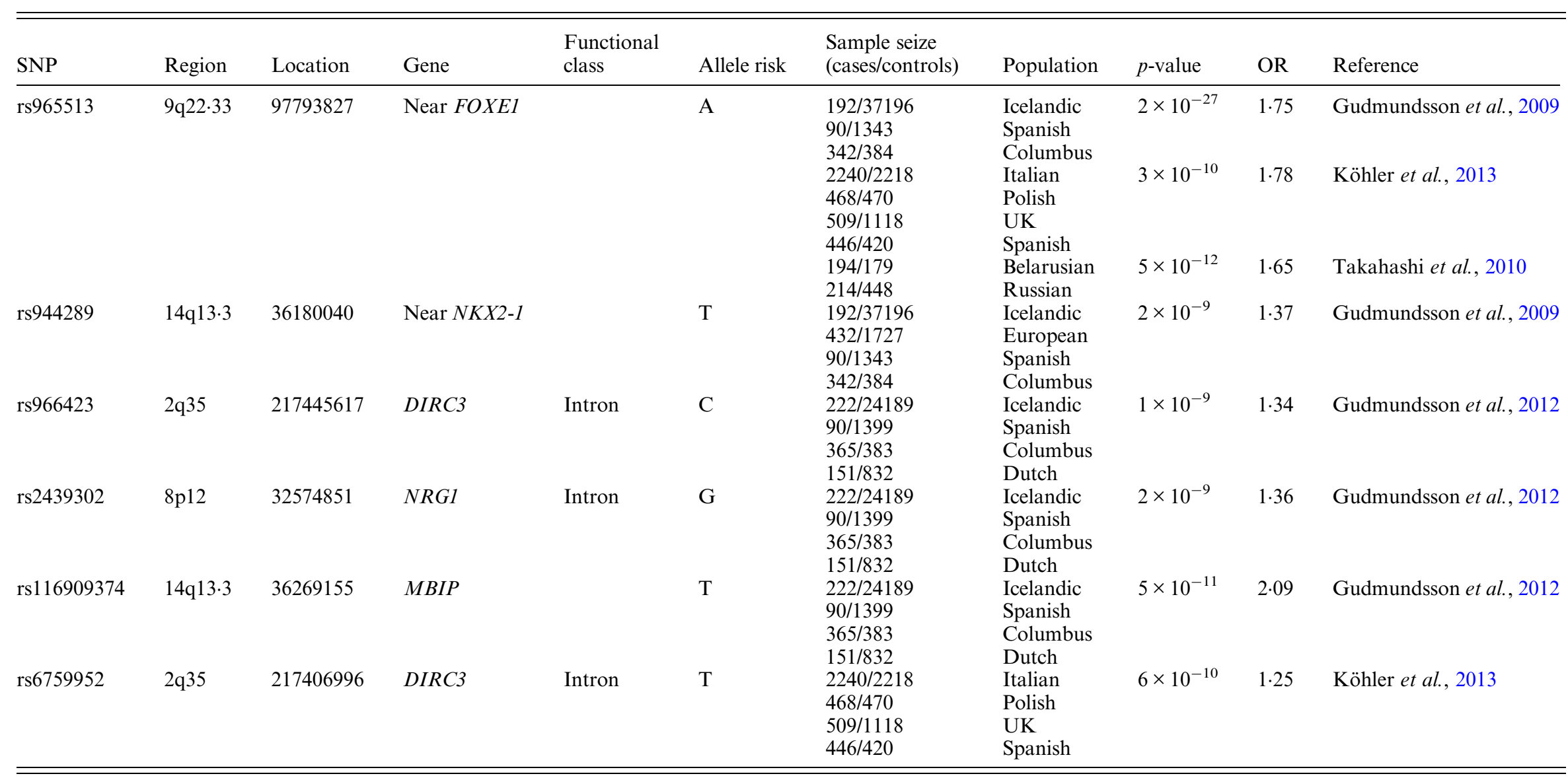


SNP

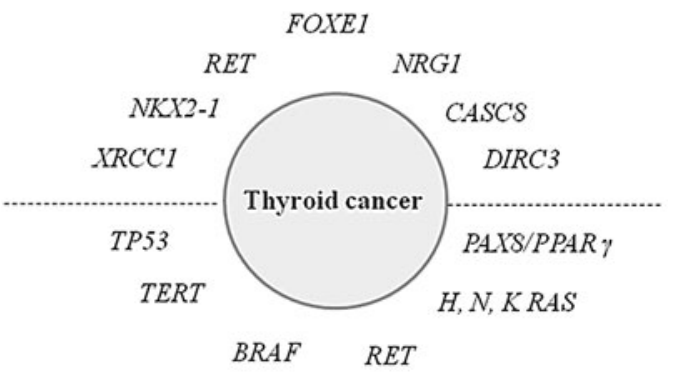

Mutation

Fig 1. Genes implicated in thyroid cancer.

fact, the first GWAS has identified 9q22.33 (rs965513) in FOXE1 and 14q13.3 (rs944289) with NKX2-1 as one of the nearby genes (Gudmundsson et al., 2009). The second GWAS focused on radiation-induced papillary TC and has confirmed the strong association with FOXE1 (Takahashi et al., 2010). The third GWAS, centred on the analysis of genetic determinants of TSH levels, not only has confirmed the $9 q 22.33$ and $14 q 13.3$ associations but also led to the identification of novel susceptibility loci at 2q35 (rs966423 in DIRC3) and 8p12 (rs2439302 in NRG1; Gudmundsson et al., 2012). A more recent GWAS has confirmed the association with DIRC3 loci by identifying additional common differentiated thyroid cancer (DTC) susceptibility loci at 2q35 (Köhler et al., 2013). Since then, many studies have been performed to evaluate these associations as well as other genomic regions in independent populations.

\section{(i) FOXE1}

Forkhead box E1 (FOXE1) is a single exon gene located at chromosome 9q22.33 encoding the transcription factor FOXE1 (or TTF-2), which likely plays a crucial role in thyroid morphogenesis. This transcription factor regulates thyroglobulin and thyroid peroxidase expression. Many association studies have been performed to investigate the role of FOXE1 polymorphisms in TC susceptibility. Several variants of this gene have been positively correlated with thyroid malignancy (Table S1). However, two common variations (rs1867277 and rs71369530) have been associated with TC risk in various ethnic groups (Matsuse et al., 2011; Gudmundsson et al., 2012; Jones et al., 2012).

The SNP rs1867277 is caused by an A/G transition in the 5'-UTR region of the gene, whereas the rs71369530 polymorphism is a polymorphic polyalanine tract (rs71369530, polyAla) just distal to its DNA-binding domain. Recently, it has been shown that the variant rs1867277 affects FOXE1 transcription. In fact, it has been reported that the A allele of this SNP increases the transcriptional activity of the FOXE1 gene promoter, by the recruitment of leucine zipper upstream stimulatory factors 1 and 2 (Landa et al., 2009). Regarding the FOXE1 polyAla tract, it has been reported that it has 11-22 alanine residues, although FOXE1 14Ala and FOXE1 16Ala account for greater than $98 \%$ of reported alleles (Kallel et al., 2010). Some studies have suggested a functional consequence for the presence of polyAla expansions $(>14)$ but not for contractions $(\leqslant 14)$. FOXE1 with 16Ala induced a stronger transactivation of the thyroglobulin promoter than the 14Ala variant (Carré et al., 2007). However, a recent study has reported a modest transcriptional impairment of 16Ala FOXE1, when compared with the function of the 14Ala variant, on FOXE1 responsive promoters, which was not attributable to differences in DNA binding (Liyanarachchi et al., 2013).

\section{(ii) $R E T$}

The rearranged during transfection (RET) protooncogene is one of the receptor tyrosine kinase, cellsurface molecules that transduce signals for cell growth and differentiation. A wide panel of SNPs in the RET gene have been reported to the curated databases but only a limited, and perhaps selected, number of these RET variants have been tested for an association (Table S1). Among them are the nonsynonymous variant G691S (rs1799939) in exon 11, the synonymous variants L769L (rs1800861) in exon 13, S836S (rs1800862) in exon 14 and S904S (rs1800863) in exon 15. These SNPs have been repeatedly implicated in the increase of MTC risk (Figlioli et al., 2013; Lantieri et al., 2013). However, the effect of $R E T$ polymorphisms on other types of TC remains unclarified. Only the SNP S836S was positively correlated with PTC but not with FTC. Despite the presence of some studies suggesting a possible role of the RET polymorphisms in MTC susceptibility, the data about the true association between MTC and RET variants were conflicting and extremely variable. The cause of this incoherence has been assigned to the limited number of patients enrolled (underpowered studies) and/or to the genetic variability among different populations (Weber \& Eng, 2005; Fugazzola et al., 2008). To avoid this high discrepancy in observed data, Weber \& Eng (2005) in their study have suggested the application of rigorous parameters to dissect out the few true RET modifiers among a vast amount of random associations and proposed an approach termed reverse phenotyping. Here, the genotype/haplotype is identified in a cohort study and then associated with phenotypical factors, analogous to an unsupervised analysis used in global gene 
expression analysis that avoids assumptions based on the phenotype to identify hidden patterns.

On the other hand, it has been shown that a synonymous polymorphism in exon 2 (Ala45Ala, rs1800858), which occurred at a lower frequency among cases of MTC, may confer a protective allele against the development of MTC (Cebrian et al., 2005). However, a recent study has shown that the $\mathrm{G}$ allele of this SNP remarkably increases the risk of TC (Huang \& Yang, 2015). The mechanism by which the silent polymorphisms may act in the development of TC may include transcript stability, mRNA structure, and DNA protein binding and protein folding (Ho et al., 2005). In the case of the nonsynonymous SNP G691S, the two amino acids, glycine in the wild-type RET protein and serine in the polymorphic RET variant, confer different electrochemical and conformational structures to the RET protein, and consequently influence the processing, folding, subcellular localization or function of the protein (Robledo et al., 2003). More recently, the functional activity of this variant has been investigated by western blot analyses and the result has showed that the fraction of Ret9-G691S protein located at the plasma membrane level was overrepresented when compared to Ret9-WT, suggesting facilitated targeting at the cell membrane for this variant (Fugazzola et al., 2008).

The relationship between the $R E T$ variants and the clinicopathological features of the disease is, yet, unclarified. In the study of Ceolin et al. (2012), no significant correlation has been observed between the RET variants analysed (G691S, L769L, S836S and S904S) and the clinicopathological parameters of the patients. Nevertheless, patients carrying haplotypes with three or four risk alleles had increased risk for lymph node and distant metastases at diagnosis. More recently, two RET SNPs (G691S and S904S) have been significantly associated with an increase in tumour size at diagnosis and a more aggressive disease (Santos et al., 2014).

\section{(iii) $\mathrm{XRCC1}$}

The X-ray repair cross complementing group 1 $(X R C C 1)$ gene encodes a scaffold protein involved in the repair of DNA single-strand breaks formed by ionizing radiation and alkylation damage. Numerous validated SNPs in the $X R C C 1$ gene have been identified, only three of which were most widely investigated including Arg194Trp on exon 6 (rs1799782, C/T), Arg280His on exon 9 (rs25489, G/A) and Arg399Gln on exon 10 (rs25487, G/A; Table S1). Over the last decade, several epidemiological studies have reported the association regarding $X R C C 1$ polymorphisms and TC risk (Fard-Esfahani et al., 2011; Ryu et al., 2011; Santos et al., 2012). However, a significant heterogeneity among studies has been observed. In fact, increased risks for DTC have been shown for Arg194Trp and Arg280His genotypes while a mild reduction of risk has been estimated for the Arg399Gln polymorphism (Fard-Esfahani et al., 2011). Nevertheless, it has been suggested in a meta-analysis involving eight different populations that the Arg399Gln polymorphism may be associated with decreased TC risk among the Caucasian population while the Arg194Trp SNP may be associated with a tendency of increased TC risk in the two larger sample size trials. But, no significant association has been found between the Arg280His polymorphism and TC (Qian et al., 2012). On the other hand, in a more recent study only the Arg194Trp SNP has been associated with increased risk of TC (Wang et al., 2015).

It has been suggested that the functional significance of the Arg194Trp polymorphism is due to its location in an evolutionarily conserved region, and the occurrence of chromosomal breaks is largely increased among cases with the Arg/Arg genotype (Vodicka et al., 2007). For the Arg399Gln polymorphism, which is located within a relatively nonconserved region between conserved residues of the BRCA1 $\mathrm{COOH}$ terminus domain, it may be associated with higher sister chromatid exchange frequency and prolonged cell cycle delay in response to ionizing radiation (Hu et al., 2001; Matullo et al., 2006). Although in the same gene, these two different SNPs may exert influence on the XRCC1 activity in different ways, thus they might have different effects on cancer risk. Regarding the Arg280His polymorphism, which is located in the PCNA-binding region of the $\mathrm{XRCC} 1$ protein, it has been suggested that this variant could potentially alter the structure of $X R C C 1$ and its ability to interact with apurinic/apyrimidinic endonuclease (Yan et al., 2009).

\section{(iv) Other genomic regions}

\section{(a) $8 q 24$}

SNPs in the 8q24 chromosomal gene-poor region, known as the 'gene desert', have been consistently implicated in GWAS as susceptibility loci for several cancer sites including TC (Neta et al., 2012). Most of these SNPs are located in the area known as cancer susceptibility candidate 8 (CASC8; Table S1). Among the important SNPs of the 8q24 chromosomal region, there is the SNP rs6983267 which has been identified as a multi-cancer SNP. This polymorphic site has been investigated in a large and multi-ethnic study and the results showed a significant association between the rs6983267 G allele and TC. In fact, it has been suggested that this variant increases disease risk by $\sim 13 \%$ (Sahasrabudhe et al., 2015). However, the precise function of this locus is still under investigation. 


\section{(b) Near FOXE1 (9q22.33)}

Since it has been shown that the SNP rs965513 (located $57 \mathrm{~kb}$ upstream of the FOXE1 gene on chromosome 9q22) was a new hot spot for TC susceptibility (Gudmundsson et al., 2009; 2012), the relationship between this polymorphic site and TC risk has been independently replicated by subsequent studies (Wang et al., 2013). It has been suggested to tag a functional variation near the FOXEl gene that contributes to an increased risk of developing TC. Besides, the variant has also been associated with low serum concentrations of thyroid stimulating hormone, and free thyroxin (Gudmundsson et al., 2012). More recently, a significant correlation has been observed between this polymorphic site and more aggressive disease (advanced stage) (Penna-Martinez et al., 2014)

\section{(c) $14 q 13$}

Among sequence variants that have been highly implicated in the aetiology of TC are the SNPs rs 944289 and rs116909374, located on 14q13 in regions containing no annotated genes. These two polymorphic sites are located within two distinct but neighbouring linkage disequilibrium regions and have been associated with low serum concentration of thyroid stimulating hormone (Gudmundsson et al., 2012). For the rs944289 polymorphism, it has been suggested that the functional significance of this variant is due to is location in the binding site for the CCAAT/enhancer binding proteins (C/EBP) $\alpha$ and $\beta$ which activated the PTCSC3 (a thyroid-specific lincRNA gene) promoter. The presence of the risk allele of this SNP decreases promoter activation by weakening the binding affinity of the $\mathrm{p} 42 \mathrm{C} / \mathrm{EBP} \alpha$ and $\mathrm{C} / \mathrm{EBP} \beta$ transcription factors. (Jendrzejewski et al., 2012).

\section{Thyroid cancer and gene mutations}

Mutation phenomenon is a rare event in TC compared to other types of malignancies where the mean percentage of mutations does not exceed one mutation per mega base. The signatures of mutational processes (mutational processes that leave idiosyncratic patterns of mutations) have been attributed mostly to unknown aetiologies (about $80 \%$ ); however, the $\mathrm{CpG}$ deamination and off-target modification of DNA by the APOBEC proteins have also been involved but with relatively low frequencies (Martincorena \& Campbell, 2015). According to the COSMIC database (COSMIC database, 2015) and the Cancer Gene Census database (www.sanger.ac.uk/CGP/census), few genes across the recurrently mutated cancer genes (79 genes among 198 genes in mutated cancer genes) have been affected by somatic mutations (nonsynonymous coding substitution or small insertion deletion) and the most affected gene was the $B R A F$ gene (Martincorena \& Campbell, 2015).

Of the several mutations that have been found in TC, only few have characterized TC (Fig. 1). These mutations have affected genes involved in cell proliferation, protein synthesis and cell survival pathways, including rearrangements of RET/PTC and PAX8/ $P P A R \gamma$, activating point mutations in BRAF serine/ threonine kinase, in the $R A S$ proto-oncogenes, in the TERT gene or inactivating mutations in the tumour suppressors gene TP53 (Table 2).

\section{(i) $B R A F$}

The $B R A F$ proto-oncogene, a serine/threonine kinase, encodes a protein belonging to the raf/mil family of serine/threonine protein kinases. This protein plays a role in regulating the MAP kinase/ERK signalling pathway, which affects cell division, differentiation and secretion. Mutations in this gene are the most common genetic event in PTC. About 40 mutations have been identified in human thyroid tumours (COSMIC database, 2015) most of which are missense substitutions (36.8\%). Most oncogenic BRAF mutations are located in the glycine-rich $\mathrm{P}$ loop (residues 462-471) and activation segment (residues 593-622) (Wan et al., 2004; Michaloglou et al., 2008).

The Glu586Lys, Val600Glu, Val600Asp, Val600Lys, Val600Arg and Lys601Glu mutations have been classified as a high kinase activity group, while nine other mutations, Gly464Glu, Gly464Val, Gly466Ala, Gly469Glu, Asn581Ser, Phe595Leu, Leu597Val, Leu597Arg and Thr599Ile, have been classified as an intermediate kinase activity group. However, four mutations, Gly466Glu, Gly466Val, Gly596Arg and Asp594Val, have lower kinase activity than basal wild-type BRAF activity (Wan et al., 2004; Michaloglou et al., 2008). The BRAF Val600 mutations mimic phosphorylation of Thr599/Ser602 (required for the activation of wild-type BRAF) and destabilize interactions between residues within the hydrogen bond network in BRAF, rendering the BRAF constitutively active (Michaloglou et al., 2008; Fratev \& Jonsdottir, 2009).

Over $90 \%$ of $B R A F$ mutations are T1799A, resulting in a substitution of glutamine for valine at amino acid codon 600 (Val600Glu, $B R A F^{\mathrm{V} 600 \mathrm{E}}$ ), while other $B R A F$ mutations are rarely reported. It has been shown that $B R A F^{\mathrm{V} 600 \mathrm{E}}$ leads to expression of a constitutively active kinase BRAF and was associated with aggressive clinicopathological characteristics (such as extrathyroidal invasion, lymph node metastasis and advanced tumour stage) (Lee et al., 2009; Lin et al., 2010), high tumour recurrence even with low stage disease (Xing et al., 2005) as well as radioiodine treatment failure in PTC (Mian et al., 2008) and high tumour related mortality (Elisei 
Table 2. Mutational profile in thyroid cancer.

\begin{tabular}{llll}
\hline \hline & \multicolumn{2}{c}{ Prevalence of common mutations in (\%) } \\
\hline Papillary carcinoma & Follicular carcinoma & Anaplastic carcinoma & Medullary carcinoma \\
\hline BRAF: $40-45^{a}$ & $R A S: 40-50^{a}$ & $T P 53: 50-80^{a}$ & $R E T / P T C: 40-50^{a}$ \\
$R E T / P T C: 10-20^{a}$ & $P A X 8 / P P A R \gamma: 30-35^{a}$ & $T E R T: 33-50^{b}$ & $R A S: 25^{a}$ \\
$R A S: 10-20^{a}$ & $T E R T: 14-36^{b}$ & $B R A F: 20-40^{a}$ & \\
& & $R A S: 20-40^{a}$ & \\
\hline \hline
\end{tabular}

${ }^{a}$ Nikiforov \& Nikiforova, 2011; ${ }^{b}$ Muzza et al., 2015.

et al., 2008). More recently, the $B R A F^{\mathrm{V} 600 \mathrm{E}}$ mutation has been investigated in a large cohort of PTC and it has been suggested that this genetic alteration represents a diverse group of tumours, consisting of at least four molecular subtypes, with variable degrees of thyroid differentiation. In this study, $B R A F^{\mathrm{V} 600 \mathrm{E}}$ has been associated with less-differentiated tumours enriched for classical and tall cell histology, and with distinct gene expression and DNA methylation patterns (Cancer Genome Atlas Research Network, 2014).

$B R A F$ fusions have been identified in PTC $(2.7 \%)$ with diverse gene patterns including SND1 (0.6\%) and $M K R N 1(0 \cdot 2 \%)$. Some of these fusions supported $B R A F$ signalling with expression and conservation of its kinase domain (MKRN1/BRAF), while others suggested an alternative activating mechanism (Cancer Genome Atlas Research Network, 2014).

\section{(ii) $R E T$}

The RET proto-oncogene has been involved in the oncogenesis of medullary and papillary thyroid carcinomas by activation of tyrosine kinases either by point mutation or rearrangement.

There are now at least 30 types of $R E T / P T C$ rearrangements involving $R E T$ and 10 different genes. RET/PTCl (fusion CCDC6 and RET) and RET/ $P T C 3$ (fusion NCOA4 and RET) are by far the most common rearrangements (COSMIC database, 2015). All of the rearrangements are due to DNA damage and result in the fusion of the RET tyrosine kinase domain to the 5 '-terminal region of heterologous genes. RET/PTC rearrangements are very common in radiation-induced tumours but have been detected in variable proportions of sporadic (nonradiation associated) papillary carcinomas. Little is known about the clinical and pathologic features of the tumours featuring RET/PTC rearrangements. Several reports have failed to show correlation of RETIPTC rearrangements with clinicopathological markers of increased morbidity (Soares et al., 1998; Tallini et al., 1998). However, RET/PTCI and RETI $P T C 3$ have been associated with less and more aggressive tumours, respectively (Nikiforov et al., 1997;
Tallini et al., 1998). A recent study performed on PTC has shown that chromosomal rearrangements including $R E T$ fusions are associated with younger age at diagnosis but not with risk of recurrence (Cancer Genome Atlas Research Network, 2014).

Activating somatic mutations in the RET protooncogene have been found in sporadic MTC with a frequency ranging from 23 to $69 \%$ of patients' tumours. The most frequent somatic mutation is Met918Thr in exon 16 (COSMIC database, 2015). This mutation has been involved in the initial event of the development of MTC and has a poor prognosis (Zedenius et al., 1995; Romei et al., 1996). Some other somatic missense point mutations as well as small oligonucleotide deletions or insertions in exons 10, 11,13 and 15 have also been reported in sporadic MTC tumours but with a considerably lower frequency (Marsh et al., 1996; Alemi et al., 1997; Kalinin \& Frilling, 1998; Uchino et al., 1999; Bugalho et al., 2000).

\section{(iii) $R A S$}

$R A S$ family proteins are small GTPases that play a role in cellular growth, differentiation, adhesion and migration. RAS mutations are among the most common genetic alterations that have been observed in thyroid tumours and that lead to constitutive activation of the $R A S$ proteins. Recent studies have reported that $10-20 \%$ of PTC and $40-50 \%$ of FTC harbour RAS mutations (Nikiforova et al., 2003; Nikiforov, 2008; Nikiforov \& Nikiforova, 2011). They have been associated with higher malignancy, poor prognoses, distant metastasis and shorter overall survival rate in poorly differentiated thyroid carcinomas (GarciaRostan et al., 2003; Volante et al., 2009). RAS mutations have also been reported in MTC (25\%) and constitute a frequent molecular event in RETnegative sporadic MTC (Nikiforov \& Nikiforova, 2011). However, their role in MTC tumourigenesis remains unclear (Oczko-Wojciechowska et al., 2015).

In the Cancer Genome Atlas project result (Cancer Genome Atlas Research Network, 2014), RAS mutations have been identified as driver mutations for PTC and have been significantly associated with highly 
differentiated tumours enriched for follicular histology and low risk of recurrence.

The $R A S$ genes consist of three families: NRAS, $H R A S$ and KRAS. RAS point mutations mostly occur in codons 12, 13 and 61 (exons 2 and 3) (Lee et al., 2013). The NRAS mutation at codon 61 (exon 3) accounted for $67-88 \%$ of all $R A S$ mutations (Vasko et al., 2003).

\section{(iv) $P A X 8 / P P A R \gamma$}

$P A X 8 / P P A R \gamma$ is formed through the translocation $\mathrm{t}(2 ; 3)(\mathrm{q} 13 ; \mathrm{p} 25)$ that fuses the promoter and 5'-coding portion of the thyroid-specific transcription factor $P A X 8$ gene to the full-length coding sequence of the nuclear receptor peroxisome proliferator-activated receptor-gamma 1 gene (Kroll et al., 2000).

$P A X 8 / P P A R \gamma$ was presumed to be specific for FTC (Kroll et al., 2000). Subsequent studies have confirmed $P A X 8 / P P A R \gamma$ presence in $30-40 \%$ of FTC and also found it in $2-13 \%$ of follicular adenomas (Dwight et al., 2003; French et al., 2003; Nikiforova et al., 2003). Additional studies have reported the occurrence of $P A X 8 / P P A R \gamma$ rearrangement in the follicular variant of PTC, typically with low frequency $(1-5 \%)$ and have reported occurrence occasionally in PTC (1.1\%) (Armstrong et al., 2014; Cancer Genome Atlas Research Network, 2014). The clinical course of the PAX8/PPAR $\gamma$ rearrangement has been indolent and the disease free survival was near $100 \%$ at 5 years (Yip et al., 2015).

\section{(v) TERT}

Telomerase reverse transcriptase (TERT) is a ribonucleoprotein polymerase that maintains telomere repeat TTAGGG at the ends of chromosomes and consists of a protein component with reverse transcriptase activity and a RNA component that serves as a template (Harrington et al., 1997). Recently, highly frequent mutations in the promoter region of TERT have been reported in many malignancies including TC (Horn et al., 2013; Huang et al., 2013; Killela et al., 2013; Vinagre et al., 2013). These mutations occur in two hot spot positions, located at $-124 \mathrm{bp}$ and -146 bp upstream from the ATG start site and confer enhanced TERT promoter activity putatively by generating a consensus binding site (GGAA) for E-26 transcription factors within the TERT promoter region (Huang et al., 2013). In the Cancer Genome Atlas Project results, TERT mutations have been identified in $9.4 \%$ of the informative papillary tumours with $7 \%$ for $\mathrm{C} 228 \mathrm{~T}, 0.3 \%$ for $\mathrm{C} 228 \mathrm{~A}$ and $2.1 \%$ for C250T substitutions (Cancer Genome Atlas Research Network, 2014).

TERT promoter mutations are an indicator of clinically aggressive tumours. In fact, these mutations have been significantly associated with distant metastases, higher stage and persistent disease. Patients with DTC harbouring TERT promoter mutations have been submitted to more radioiodine treatments with higher cumulative dose and to more treatment modalities (Melo et al., 2014). Also, TERT mutations have been correlated with disease specific mortality (Melo et al., 2014). These associations were consistent with the published results of the Cancer Genome Atlas Research Project, where TERT mutations have been associated with older age as well as higher risk of recurrence and it has been suggested that these mutations may be used to identify high risk patients (Cancer Genome Atlas Research Network, 2014). Recently, it has been shown that the prognostic value of TERT mutations is significantly stronger than that of $B R A F^{\mathrm{V} 600 \mathrm{E}}$ (Muzza et al., 2015).

\section{(vi) TP53}

Tumour suppressor protein (TP53) is a transcription factor that regulates the expression of target genes in response to diverse cellular stresses, thereby inducing cell cycle arrest, apoptosis, senescence, DNA repair or changes in metabolism. Mutations in the TP53 gene are a rare event in well DTC (PTC and FTC), while they are frequent in more advanced forms of carcinoma. In fact, TP53 mutations are a major event in poor DTC and anaplastic TC having a prevalence of 27 and $48 \%$, respectively (Guerra et al., 2013; Pita et al., 2014). Virtually, all the mutations that have been reported are located in the hot spot region located between exons 5 and 9, where codon 273 is the one that is more often affected (Donghi et al., 1993; Fagin et al., 1993).

\section{Conclusion}

In summary, the genetic predisposition of $\mathrm{TC}$ has been highlighted in several studies. Numerous mutations and polymorphisms have been associated with this type of malignancy. The most affected genes are those involved in DNA repair, signal transduction and cell cycle control. Also, the importance of some genetic elements located on gene-poor regions was highlighted. These and other emerging molecular markers may provide additional approaches to thyroid tumour classification (such as suggested in the Cancer Genome Atlas Project), and may stimulate the development of novel approaches to tumour diagnosis and additional parameters for prognostic assessment as well as potential biologic therapeutic strategies. However, large prospective studies are required to further evaluate the diagnostic and prognostic power of these genetic elements.

This work was supported by the Ministry of Higher Education and Scientific Research, Tunisia. 


\section{Declaration of interest}

None.

\section{Supplementary material}

The online supplementary material can be found available at http://dx.doi.org/10.1017/S0016672316000057

\section{References}

Alemi, M., Lucas, S. D., Sallstrom, J. F., Bergholm, U., Akerstrom, G. \& Wilander, E. (1997). A complex nine base pair deletion in RET exon 11 common in sporadic medullary thyroid carcinoma. Oncogene 14, 2041-2045.

Armstrong, M. J., Yang, H., Yip, L., Ohori, N. P., McCoy, K. L., Stang, M. T., Hodak, S. P., Nikiforova, M. N., Carty, S. E. \& Nikiforov, Y. E. (2014). PAX8/PPAR $\gamma$ rearrangement in thyroid nodules predicts follicular-pattern carcinomas, in particular the encapsulated follicular variant of papillary carcinoma. Thyroid 24(9), 1369-1374.

Bugalho, M. J., Coelho, I. \& Sobrinho, L. G. (2000). Somatic trinucleotide change encompassing codons 882 and 883 of the RET proto-oncogene in a patient with sporadic medullary thyroid carcinoma. European Journal of Endocrinology 142, 573-575.

Cancer Genome Atlas Research Network (2014). Integrated genomic characterization of papillary thyroid carcinoma. Cell 159(3), 676-690.

Carré, A., Castanet, M., Sura-Trueba, S., Szinnai, G., Van Vliet, G., Trochet, D., Amiel, J., Léger, J., Czernichow, P., Scotet, V. \& Polak, M. (2007). Polymorphic length of FOXE1 alanine stretch: evidence for genetic susceptibility to thyroid dysgenesis. Human Genetics 122, 467-476.

Ceolin, L., Siqueira, D. R., Ferreira, C. V., Romitti, M., Maia, S. C., Leiria, L., Crispim, D., Ashton-Prolla, P. \& Maia, A. L. (2012) Additive effect of $R E T$ polymorphisms on sporadic medullary thyroid carcinoma susceptibility and tumor aggressiveness. European Journal of Endocrinology 166(5), 847-854.

COSMIC database (2015). Catalogue of somatic mutation in cancer. Available at www.sanger.ac.uk/CGP/cosmic (accessed 20 September 2015).

Cebrian, A., Lesueur, F., Martin, S., Leyland, J., Ahmed, S., Luccarini, C., Smith, P. L., Luben, R., Whittaker, J., Pharoah, P. D., Dunning, A. M. \& Ponder, B. A. (2005). Polymorphisms in the initiators of RET (rearranged during transfection) signaling pathway and susceptibility to sporadic medullary thyroid carcinoma. Journal of Clinical Endocrinology and Metabolism 90, 6268-6274.

DeLellis, R. A. (2006). Pathology and genetics of thyroid carcinoma. Journal of Surgical Oncology 94, 662-669.

Donghi, R., Longoni, A., Pilotti, S., Michieli, P., Della Porta, G. \& Pierotti, M. A. (1993). Gene p53 mutations are restricted to poorly differentiated and undifferentiated carcinomas of the thyroid gland. Journal of Clinical Investigation 91(4), 1753-1760.

Dwight, T., Thoppe, S. R., Foukakis, T., Lui, W. O., Wallin, G., Hoog, A., Frisk, T., Larsson, C. \& Zedenius, J. (2003). Involvement of the PAX8/peroxisome proliferator-activated receptor gamma rearrangement in follicular thyroid tumors. Journal of Clinical Endocrinology and Metabolism 88, 4440-4445.
Elisei, R., Ugolini, C., Viola, D., Lupi, C., Biagini, A., Giannini, R., Romei, C., Miccoli, P., Pinchera, A. \& Basolo, F. (2008). BRAF (V600E) mutation and outcome of patients with papillary thyroid carcinoma: a 15-year median follow-up study. Journal of Clinical Endocrinology and Metabolism 93(10), 3943-3949.

Fagin, J. A., Matsuo, K., Karmakar, A., Chen, D. L., Tang, S. H. \& Koeffler, H. P. (1993). High prevalence of mutations of the p53 gene in poorly differentiated human thyroid carcinomas. Journal of Clinical Investigation 91(1), 179-184.

Farahati, J., Geling, M., Mader, U., Mortl, M., Luster, M., Muller, J. G., Flentje, M. \& Reiners, C. (2004). Changing trends of incidence and prognosis of thyroid carcinoma in lower Franconia, Germany, from 1981-1995. Thyroid 14, 141-147.

Fard-Esfahani, P., Fard-Esfahani, A., Fayaz, S., Ghanbarzadeh, B., Saidi, P., Mohabati, R., Bidoki, S. K. \& Majdi, M. (2011). Association of Arg194Trp, Arg280His and Arg399Gln polymorphisms in X-ray repair cross-complementing group 1 gene and risk of differentiated thyroid carcinoma in Iran. Iranian Biomedical Journal 15, 73-78.

Figlioli, G., Landi, S., Romei, C., Elisei, R. \& Gemignani, F. (2013). Medullary thyroid carcinoma (MTC) and RET proto-oncogene: mutation spectrum in the familial cases and a meta-analysis of studies on the sporadic form. Mutation Research 752, 36-44.

Fratev, F. F. \& Jonsdottir, S. O. (2009). An in silico study of the molecular basis of B-RAF activation and conformational stability. BMC Structural Biology 9, 47.

French, C.A., Alexander, E. K., Cibas, E. S., Nose, V., Laguette, J., Faquin, W., Garber, J., Moore, F., Fletcher, J. A., Larsen, P. R. \& Kroll, T. G. (2003). Genetic and biological subgroups of low-stage follicular thyroid cancer. American Journal of Pathology 162, 1053-1060.

Fugazzola, L., Muzza, M., Mian, C., Cordella, D., Barollo, S., Alberti, L., Cirello, V., Dazzi, D., Girelli, M. E., Opocher, G., Beck-Peccoz, P. \& Persani, L. (2008). RET genotypes in sporadic medullary thyroid cancer: studies in a large Italian series. Clinical Endocrinology 69(3), 418-425.

Garcia-Rostan, G., Zhao, H., Camp, R. L., Pollan, M., Herrero, A., Pardo, J., Wu, R., Carcangiu, M. L., Costa, J. \& Tallini, G. (2003). Ras mutations are associated with aggressive tumor phenotypes and poor prognosis in thyroid cancer. Journal of Clinical Oncology 21 (17), 3226-3235.

Gudmundsson, J., Sulem, P., Gudbjartsson, D. F., Jonasson, J. G., Masson, G., He, H., Jonasdottir, A., Sigurdsson, A., Stacey, S. N., Johannsdottir, H., Helgadottir, H. T., Li, W., Nagy, R., Ringel, M. D., Kloos, R.T., de Visser, M. C., Plantinga, T.S., den Heijer, M., Aguillo, E., Panadero, A., Prats, E., GarciaCastaño, A., De Juan, A., Rivera, F., Walters, G. B., Bjarnason, H., Tryggvadottir, L., Eyjolfsson, G. I., Bjornsdottir, U.S., Holm, H., Olafsson, I., Kristjansson, K., Kristvinsson, H., Magnusson, O.T., Thorleifsson, G., Gulcher, J. R., Kong, A., Kiemeney, L. A., Jonsson, T., Hjartarson, H., Mayordomo, J. I., Netea-Maier, R.T., de la Chapelle, A., Hrafnkelsson, J., Thorsteinsdottir, U., Rafnar, T. \& Stefansson, K. (2012). Discovery of common variants associated with low TSH levels and thyroid cancer risk. Nature Genetics 44, 319-322.

Gudmundsson, J., Sulem, P., Gudbjartsson, D. F., Jonasson, J. G., Sigurdsson, A., Bergthorsson, J. T., He, 
H., Blondal, T., Geller, F., Jakobsdottir, M., Magnusdottir, D. N., Matthiasdottir, S., Stacey, S. N., Skarphedinsson, O. B., Helgadottir, H., Li, W., Nagy, R., Aguillo, E., Faure, E., Prats, E., Saez, B., Martinez, M., Eyjolfsson, G. I., Bjornsdottir, U.S., Holm, H., Kristjansson, K., Frigge, M. L., Kristvinsson, H., Gulcher, J. R., Jonsson, T., Rafnar, T., Hjartarsson, H., Mayordomo, J. I., de la Chapelle, A., Hrafnkelsson, J., Thorsteinsdottir, U., Kong, A. \& Stefansson, K. (2009). Common variants on $9 \mathrm{q} 22.33$ and $14 \mathrm{q} 13.3$ predispose to thyroid cancer in European populations. Nature Genetics 41, 460-464.

Guerra, A., Di Crescenzo, V., Garzi, A., Cinelli, M., Carlomagno, C., Tonacchera, M., Zeppa, P. \& Vitale, M. (2013). Genetic mutations in the treatment of anaplastic thyroid cancer: a systematic review. BMC Surgery 13 (2), S44.

Harrington, L., McPhail, T., Mar, V., Zhou, W., Oulton, R., Bass, M. B., Arruda, I. \& Robinson, M. O. (1997). A mammalian telomerase-associated protein. Science 275, 973-977.

Ho, T., Li, G., Zhao, C., Wei, Q. \& Sturgis, E. M. (2005). $R E T$ polymorphisms and haplotypes and risk of differentiated thyroid cancer. Laryngoscope 115, 1035-1041.

Horn, S., Figl, A., Rachakonda, P. S., Fischer, C., Sucker, A., Gast, A., Kadel, S., Moll, I., Nagore, E., Hemminki, K., Schadendorf, D. \& Kumar, R. (2013). TERT promoter mutations in familial and sporadic melanoma. Science 339, 959-961.

Hu, J. J., Smith, T. R., Miller, M. S., Mohrenweiser, H. W., Golden, A. \& Case, L. D. (2001). Amino acid substitution variants of $A P E 1$ and $X R C C 1$ genes associated with ionizing radiation sensitivity. Carcinogenesis 22(6), 917-922.

Huang, F. W., Hodis, E., Xu, M. J., Kryukov, G. V., Chin, L. \& Garraway, L. A. (2013). Highly recurrent TERT promoter mutations in human melanoma. Science 339, 957-959.

Huang, R.X. \& Yang, F. (2015). RET polymorphisms might be the risk factors for thyroid cancer. International Journal of Clinical and. Experimental Pathology 8(5), 5793-5797.

Jendrzejewski, J., He, H., Radomska, H. S., Li, W., Tomsic, J., Liyanarachchi, S., Davuluri, R. V., Nagy, R. \& de la Chapelle, A. (2012). The polymorphism rs944289 predisposes to papillary thyroid carcinoma through a large intergenic noncoding RNA gene of tumor suppressor type. Proceedings of the National Academy of Sciences of the United States of America 109(22), 8646-8651.

Jones, A. M., Howarth, K. M., Martin, L., Gorman, M., Mihai, R., Moss, L., Auton, A., Lemon, C., Mehanna, H., Mohan, H., Clarke, S. E., Wadsley, J., Macias, E., Coatesworth, A., Beasley, M., Roques, T., Martin, C., Ryan, P., Gerrard, G., Power, D., Bremmer, C., Tomlinson, I. \& Carvajal-Carmona, L. G. (2012). Thyroid cancer susceptibility polymorphisms: confirmation of loci on chromosomes $9 \mathrm{q} 22$ and $14 \mathrm{q} 13$, validation of a recessive $8 \mathrm{q} 24$ locus and failure to replicate a locus on 5q24. Journal of Medical Genetics 49, 158-163.

Kalinin, V. \& Frilling, A. (1998). 27-bp deletion in the RET protooncogene as a somatic mutation associated with medullary thyroid carcinoma. Journal of Molecular Medicine 76, 365-367.

Kallel, R., Belguith-Maalej, S., Akdi, A., Mnif, M., Charfeddine, I., Galofré, P., Ghorbel, A., Abid, M., Marcos, R., Ayadi, H., Velázquez, A. \& Hadj Kacem, H. (2010). Genetic investigation of FOXE1 polyalanine tract in thyroid diseases: new insight on the role of FOXE1 in thyroid carcinoma. Cancer Biomarkers 8, 43-51.
Kang, H. J., Kim, S. W., Kim, H. J., Ahn, S. J., Bae, J. Y., Park, S. K., Kang, D., Hirvonen, A., Choe, K. J. \& Noh, D. Y. (2002). Polymorphisms in the estrogen receptor-alpha gene and breast cancer risk. Cancer Letters 178, 175-180.

Killela, P. J., Reitman, Z. J., Jiao, Y., Bettegowda, C., Agrawal, N., Diaz, L. A., Friedman, A. H., Friedman, H., Gallia, G. L., Giovanella, B. C., Grollman, A. P., He, T. C., He, Y., Hruban, R. H., Jallo, G. I., Mandahl, N., Meeker, A. K., Mertens, F., Netto, G. J., Rasheed, B. A., Riggins, G. J., Rosenquist, T. A., Schiffman, M., Shih, I. M., Theodorescu, D., Torbenson, M. S., Velculescu, V. E., Wang, T. L., Wentzensen, N., Wood, L. D., Zhang, M., McLendon, R. E., Bigner, D. D., Kinzler, K. W., Vogelstein, B., Papadopoulos, N. \& Yan, H. (2013). TERT promoter mutations occur frequently in gliomas and a subset of tumors derived from cells with low rates of self-renewal. Proceedings of the National Academy of Sciences of the United States of America 110, 6021-6026.

Köhler, A., Chen, B., Gemignani, F., Elisei, R., Romei, C., Figlioli, G., Cipollini, M., Cristaudo, A., Bambi, F., Hoffmann, P., Herms, S., Kalemba, M., Kula, D., Harris, S., Broderick, P., Houlston, R., Pastor, S., Marcos, R., Velázquez, A., Jarzab, B., Hemminki, K., Landi, S. \& Försti, A. (2013). Genome-wide association study on differentiated thyroid cancer. Journal of Clinical Endocrinology and Metabolism 98(10), E1674E1681.

Kondo, T., Ezzat, S. \& Asa, S. L. (2006). Pathogenetic mechanisms in thyroid follicular-cell neoplasia. Nature Reviews Cancer 6, 292-306.

Kroll, T. G., Sarraf, P., Pecciarini, L., Chen, C. J., Mueller, E., Spiegelman, B. M. \& Fletcher, J. A. (2000). PAX8PPARgammal fusion oncogene in human thyroid carcinoma [corrected]. Science 289, 1357-1360.

Landa, I., Ruiz-Llorente, S., Montero-Conde, C., IngladaPérez, L., Schiavi, F., Leskelä, S., Pita, G., Milne, R., Maravall, J., Ramos, I., Andía, V., Rodríguez-Poyo, P., Jara-Albarrán, A., Meoro, A., del Peso, C., Arribas, L., Iglesias, P., Caballero, J., Serrano, J., Picó, A., Pomares, F., Giménez, G., López-Mondéjar, P., Castello, R., Merante-Boschin, I., Pelizzo, M. R., Mauricio, D., Opocher, G., Rodríguez-Antona, C., González-Neira, A., Matías-Guiu, X., Santisteban, P. \& Robledo, M. (2009). The variant rs1867277 in FOXE1 gene confers thyroid cancer susceptibility through the recruitment of USF1/USF2 transcription factors. PLoS Genetics 5(9), e1000637.

Lantieri, F., Caroli, F., Ceccherini, I. \& Griseri, P. (2013). The involvement of the RET variant G691S in medullary thyroid carcinoma enlightened by a meta-analysis study. International Journal of Cancer 132, 2808-2819.

Lee, S. R., Jung, C. K., Kim, T. E., Bae, J. S., Jung, S. L., Choi, Y. J. \& Kang, C. S. (2013). Molecular genotyping of follicular variant of papillary thyroid carcinoma correlates with diagnostic category of fine-needle aspiration cytology: values of $R A S$ mutation testing. Thyroid 23(11), 1416-1422.

Lee, X., Gao, M., Ji, Y., Yu, Y., Feng, Y., Li, Y., Zhang, Y., Cheng, W. \& Zhao, W. (2009). Analysis of differential $B R A F(\mathrm{~V} 600 \mathrm{E})$ mutational status in high aggressive papillary thyroid microcarcinoma. Annals of Surgical Oncology 16, 240-245.

Leenhardt, L., Ménégaux, F., Franc, B., Hoang, C., Salem, S., Bernier, M. O., Dupasquier-Fédiaevsky, L., Le Marois, E., Rouxel, A., Chigot, J. P., Chérié-Challine, L. \& Aurengo, A. (2005). Cancers de la thyroïde. EM consulte. Available 
at www.em-consulte.com/article/29159/cancers-de-la-thyroide (accessed 25 September 2015).

Lin, K. L., Wang, O. C., Zhang, X. H., Dai, X. X., Hu, X. Q. \& Qu, J. M. (2010). The BRAF mutation is predictive of aggressive clinicopathological characteristics in papillary thyroid microcarcinoma. Annals of Surgical Oncology 17, 3294-3300.

Liyanarachchi, S., Wojcicka, A., Li, W., Czetwertynska, M., Stachlewska, E., Nagy, R., Hoag, K., Wen, B., Ploski, R., Ringel, M. D., Kozłowicz-Gudzinska, I., Gierlikowski, W., Jazdzewski, K., He, H. \& de la Chapelle, A. (2013). Cumulative risk impact of five genetic variants associated with papillary thyroid carcinoma. Thyroid 23, 1532-1540.

Marsh, D. J., Scott, D. A., Eng, C., Learoyd, D. L., Capes, A. G., Pojer, R., Richardson, A. L., Houghton, C., Mulligan, L. M., Ponder, B. A. J. \& Robinson, B. G. (1996). Germline and somatic mutations in an oncogene: RET mutations in inherited medullary thyroid carcinoma. Cancer Research 56, 1241-1243.

Martincorena, I. \& Campbell, P. J. (2015). Somatic mutation in cancer and normal cells. Science 349(6255), $1483-1489$

Matsuse, M., Takahashi, M., Mitsutake, N., Nishihara, E., Hirokawa, M., Kawaguchi, T., Rogounovitch, T., Saenko, V., Bychkov, A., Suzuki, K., Matsuo, K., Tajima, K., Miyauchi, A., Yamada, R., Matsuda, F. \& Yamashita, S. (2011). The FOXE1 and NKX2-1 loci are associated with susceptibility to papillary thyroid carcinoma in the Japanese population. Journal of Medical Genetics 48, 645-648.

Matullo, G., Dunning, A. M., Guarrera, S., Baynes, C., Polidoro, S., Garte, S., Autrup, H., Malaveille, C., Peluso, M., Airoldi, L., Veglia, F., Gormally, E., Hoek, G., Krzyzanowski, M., Overvad, K., Raaschou-Nielsen, O., Clavel-Chapelon, F., Linseisen, J., Boeing, H., Trichopoulou, A., Palli, D., Krogh, V., Tumino, R., Panico, S., Bueno-De-Mesquita, H. B., Peeters, P. H., Lund, E., Pera, G., Martinez, C., Dorronsoro, M., Barricarte, A., Tormo, M. J., Quiros, J. R., Day, N. E., Key, T. J., Saracci, R., Kaaks, R., Riboli, E. \& Vineis, P. (2006). DNA repair polymorphisms and cancer risk in nonsmokers in a cohort study. Carcinogenesis 27(5), 997-1007.

Melo, M., da Rocha, A. G., Vinagre, J., Batista, R., Peixoto, J., Tavares, C., Celestino, R., Almeida, A., Salgado, C., Eloy, C., Castro, P., Prazeres, H., Lima, J., Amaro, T., Lobo, C., Martins, M. J., Moura, M., Cavaco, B., Leite, V., Cameselle-Teijeiro, J. M., Carrilho, F., Carvalheiro, M., Máximo, V., Sobrinho-Simões, M. \& Soares, P. (2014). TERT promoter mutations are a major indicator of poor outcome in differentiated thyroid carcinomas. Journal of Clinical Endocrinology and Metabolism 99(5), E754-E765.

Mian, C., Barollo, S., Pennelli, G., Pavan, N., Rugge, M., Pelizzo, M. R., Mazzarotto, R., Casara, D., Nacamulli, D., Mantero, F., Opocher, G., Busnardo, B. \& Girelli, M. E. (2008). Molecular characteristics in papillary thyroid cancers (PTCs) with no 131I uptake. Clinical Endocrinology 68, 108-116.

Michaloglou, C., Vredeveld, L. C., Mooi, W. J. \& Peeper, D.S. (2008). BRAF (E600) in benign and malignant human tumours. Oncogene 27, 877-895.

Muzza, M., Colombo, C., Rossi, S., Tosi, D., Cirello, V., Perrino, M., De Leo, S., Magnani, E., Pignatti, E., Vigo, B., Simoni, M., Bulfamante, G., Vicentini, L. \& Fugazzola, L. (2015). Telomerase in differentiated thyroid cancer: promoter mutations, expression and localization. Molecular and Cellular Endocrinology 399, 288-295.
Neta, G., Yu, C. L., Brenner, A., Gu, F., Hutchinson, A., Pfeiffer, R., Sturgis, E. M., Xu, L., Linet, M.S., Alexander, B. H., Chanock, S. \& Sigurdson, A. J. (2012). Common genetic variants in the 8q24 region and risk of papillary thyroid cancer. Laryngoscope 122(5), 1040-1042.

Nikiforov, Y. E. \& Nikiforova, M. N. (2011). Molecular genetics and diagnosis of thyroid cancer. Nature Reviews Endocrinology 7, 569-580.

Nikiforov, Y.E. (2008). Thyroid carcinoma: molecular pathways and therapeutic targets Modern Pathology 21 (2), S37-S43.

Nikiforov, Y. E., Rowland, J. M., Bove, K. E., MonforteMunoz, H. \& Fagin, J. A. (1997). Distinct pattern of ret oncogene rearrangements in morphologic variants of radiation induced and sporadic thyroid papillary carcinomas in children. Cancer Research 57, 1690-1694.

Nikiforova, M. N. \& Nikiforov, Y. E. (2009). Molecular diagnostics and predictors in thyroid cancer. Thyroid 19 (12), 1351-1361.

Nikiforova, M. N., Lynch, R. A., Biddinger, P. W., Alexander, E. K., Dorn, G. W. 2nd, Tallini, G., Kroll, T. G. \& Nikiforov, Y.E. (2003). RAS point mutations and PAX8-PPAR gamma rearrangement in thyroid tumors: evidence for distinct molecular pathways in thyroid follicular carcinoma. Journal of Clinical Endocrinology and Metabolism 88, 2318-2326.

Oczko-Wojciechowska, M., Pfeifer, A., Rusinek, D., Pawlaczek, A., Zebracka-Gala, J., Kowalska, M., Kowal, M., Swierniak, M., Krajewska, J., Gawlik, T., Chmielik, E., Czarniecka, A., Szpak-Ulczok, S. \& Jarzab, B. (2015). The prevalence of somatic $R A S$ mutations in medullary thyroid cancer - a Polish population study. Endokrynologia Polska 66(2), 121-125.

Penna-Martinez, M., Epp, F., Kahles, H., Ramos-Lopez, E., Hinsch, N., Hansmann, M. L., Selkinski, I., Grünwald, F., Holzer, K., Bechstein, W. O., Zeuzem, S., Vorländer, C. \& Badenhoop, K. (2014). FOXE1 association with differentiated thyroid cancer and its progression. Thyroid 24(5), 845-851.

Pita, J. M., Figueiredo, I. F., Moura, M. M., Leite, V. \& Cavaco, B. M. (2014). Cell cycle deregulation and TP53 and $R A S$ mutations are major events in poorly differentiated and undifferentiated thyroid carcinomas. Journal of Clinical Endocrinology and Metabolism 99(3), E497-E507.

Qian, K., Liu, K. J., Xu, F., Chen, X. Y., Chen, G. N., Yi, W. J., Zhou, E.X. \& Tang, Z.H. (2012). X-ray repair cross-complementing group 1 (XRCC1) genetic polymorphisms and thyroid carcinoma risk: a meta-analysis. Asian Pacific Journal of Cancer Prevention 13(12), 6385 6390.

Robledo, M., Gil, L., Pollán, M., Cebrián, A., Ruíz, S., Azañedo, M., Benitez, J., Menárguez, J. \& Rojas, J. M. (2003). Polymorphisms G691S/S904S of RET as genetic modifiers of MEN 2A. Cancer Research 63, 1814-1817.

Romei, C., Elisei, R., Pinchera, A., Ceccherini, I., Molinaro, E., Mancusi, F., Martino, E., Romeo, G. \& Pacini, F. (1996). Somatic mutations of the ret protooncogene in sporadic medullary thyroid carcinoma are not restricted to exon 16 and are associated with tumor recurrence. Journal of Clinical Endocrinology and Metabolism 81, $1619-1622$.

Ryu, R. A., Tae, K., Min, H. J., Jeong, J. H., Cho, S. H., Lee, S. H. \& Ahn, Y.H. (2011). XRCC1 polymorphisms and risk of papillary thyroid carcinoma in a Korean sample. Journal of Korean Medical Science 26, 991-995. 
Sahasrabudhe, R., Estrada, A., Lott, P., Martin, L., Polanco Echeverry, G., Velez, A., Neta, G., Takahasi, M., Saenko, V., Mitsutake, N., Jaeguer, E., Duque, C.S., Rios, A., Bohorquez, M., Prieto, R., Criollo, A., Echeverry, M., Tomlinson, I., TCUKIN and CORGI Consortiums, Carmona, L. G. \& JTCMS Consortium (2015). The $8 \mathrm{q} 24$ rs6983267 $\mathrm{G}$ variant is associated with increased thyroid cancer risk. Endocrine Related Cancer 22(5), 841-849.

Santos, L. S., Branco, S. C., Silva, S. N., Azevedo, A. P., Gil, O. M., Manita, I., Ferreira, T.C., Limbert, E., Rueff, J. \& Gaspar, J. F. (2012). Polymorphisms in base excision repair genes and thyroid cancer risk. Oncology Reports 28, 1859-1868.

Santos, M., Azevedo, T., Martins, T., Rodrigues, F. J. \& Lemos, M. C. (2014). Association of RET genetic polymorphisms and haplotypes with papillary thyroid carcinoma in the Portuguese population: a case-control study. PLoS One 9(10), e109822.

Soares, P., Fonseca, E., Wynford-Thomas, D. \& SobrinhoSimões, M. (1998). Sporadic ret-rearranged papillary carcinoma of the thyroid: a subset of slow growing, less aggressive thyroid neoplasms? Journal of Pathology 185, 71-78.

Takahashi, M, Saenko, V. A., Rogounovitch, T. I., Kawaguchi, T., Drozd, V. M., Takigawa-Imamura, H., Akulevich, N. M., Ratanajaraya, C., Mitsutake, N., Takamura, N., Danilova, L. I., Lushchik, M. L., Demidchik, Y. E., Heath, S., Yamada, R., Lathrop, M., Matsuda, F. \& Yamashita, S. (2010). The FOXE1 locus is a major genetic determinant for radiation-related thyroid carcinoma in Chernobyl. Human Molecular Genetics 19(12), 2516-2523.

Tallini, G., Santoro, M., Helie, M., Carlomagno, F., Salvatore, G., Chiappetta, G., Carcangiu, M. L. \& Fusco, A. (1998). RET/PTC oncogene activation defines a subset of papillary thyroid carcinomas lacking evidence of progression to poorly differentiated or undifferentiated tumor phenotypes. Clinical Cancer Research 4, 287-294.

Uchino, S., Noguchi, S., Yamashita, H., Sato, M., Adachi, M., Yamashita, H., Watanabe, S., Ohshima, A., Mitsuyama, S., Iwashita, T. \& Takahashi, M. (1999). Somatic mutations in RET exons 12 and 15 in sporadic medullary thyroid carcinomas: different spectrum of mutations in sporadic type from hereditary type. Japanese Journal of Cancer Research 90, 1231-1237.

Vasko, V., Ferrand, M., di Cristofaro, J., Carayon, P., Henry, J. F. \& DeMicco, C. (2003). Specific pattern of $R A S$ oncogene mutations in follicular thyroid tumors. Journal of Clinical Endocrinology and Metabolism 88(6), 2745-2752.

Vinagre, J., Almeida, A., Populo, H., Batista, R., Lyra, J., Pinto, V., Coelho, R., Celestino, R., Prazeres, H., Lima, L., Melo, M., da Rocha, A. G., Preto, A., Castro, P., Castro, L., Pardal, F., Lopes, J. M., Santos, L. L., Reis, R. M., Cameselle-Teijeiro, J., Sobrinho-Simões, M., Lima, J., Máximo, V. \& Soares, P. (2013). Frequency of TERT promoter mutations in human cancers. Nature Communications 4, 2185.

Vodicka, P., Stetina, R., Polakova, V., Tulupova, E., Naccarati, A., Vodickova, L., Kumar, R., Hanova, M.,
Pardini, B., Slyskova, J., Musak, L., De Palma, G., Soucek, P. \& Hemminki, K. (2007). Association of DNA repair polymorphisms with DNA repair functional outcomes in healthy human subjects. Carcinogenesis $\mathbf{2 8}$ (3), 657-664.

Volante, M., Rapa, I., Gandhi, M., Bussolati, G., Giachino, D., Papotti, M. \& Nikiforov, Y. E. (2009). RAS mutations are the predominant molecular alteration in poorly differentiated thyroid carcinomas and bear prognostic impact. Journal of Clinical Endocrinology and Metabolism 94 (12), 4735-4741.

Wan, P. T., Garnett, M. J., Roe, S. M., Lee, S., NiculescuDuvaz, D., Good, V. M., Jones, C. M., Marshall, C. J., Springer, C. J., Barford, D. \& Marais, R. (2004). Mechanism of activation of the RAF-ERK signaling pathway by oncogenic mutations of $B-R A F$. Cell 116, 855-867.

Wang, X., Zhang, K., Liu, X., Liu, B. \& Wang, Z. (2015). Association between $X R C C 1$ and $X R C C 3$ gene polymorphisms and risk of thyroid cancer. International Journal of Clinical and Experimental Pathology 8(3), 3160-3167.

Wang, Y. L., Feng, S. H., Guo, S. C., Wei, W. J., Li, D. S., Wang, Y., Wang, X., Wang, Z. Y., Ma, Y. Y., Jin, L., Ji, Q. H. \& Wang, J. C. (2013). Confirmation of papillary thyroid cancer susceptibility loci identified by genomewide association studies of chromosomes 14q13, 9q22, 2 q35 and 8 p12 in a Chinese population. Journal of Medical Genetics 50, 689-695.

Weber, F. \& Eng, C. (2005). Editorial: germline variants within RET: clinical utility or scientific playtoy? Journal of Clinical Endocrinology and Metabolism 90(11), $6334-6336$.

Xing, M., Westra, W.H., Tufano, R.P., Cohen, Y., Rosenbaum, E., Rhoden, K. J., Carson, K. A., Vasko, V., Larin, A., Tallini, G., Tolaney, S., Holt, E. H., Hui, P., Umbricht, C. B., Basaria, S., Ewertz, M., Tufaro, A. P., Califano, J. A., Ringel, M. D., Zeiger, M. A., Sidransky, D. \& Ladenson, P. W. (2005). BRAF mutation predicts a poorer clinical prognosis for papillary thyroid cancer. Journal of Clinical Endocrinology and Metabolism 90, 6373-6379.

Yan, L., Yanan, D., Donglan, S., Na, W., Rongmiao, Z. \& Zhifeng, C. (2009). Polymorphisms of XRCC1 gene and risk of gastric cardiac adenocarcinoma. Diseases of the Esophagus 22, 396-401.

Yip, L., Nikiforova, M. N., Yoo, J. Y., McCoy, K. L., Stang, M. T., Armstrong, M. J., Nicholson, K. J., Ohori, N. P., Coyne, C., Hodak, S. P., Ferris, R. L., LeBeau, S. O., Nikiforov, Y.E. \& Carty, S. E. (2015). Tumor genotype determines phenotype and disease-related outcomes in thyroid cancer: a study of 1510 patients. Annals of Surgery 262(3), 519-525.

Zedenius, J., Larsson, C., Bergholm, U., Bovee, J., Svensson, A., Hallengren, B., Grimelius, L., Backdahl, M., Weber, G. \& Wallin, G. (1995). Mutations of codon 918 in the RET proto-oncogene correlate to poor prognosis in sporadic medullary thyroid carcinomas. Journal of Clinical Endocrinology and Metabolism 80, 3088-3090. 